\title{
Erratum to: Accumulation pattern and distribution of polycyclic aromatic hydrocarbons (PAHs) in liver tissues of seven species of birds from Ahmedabad, India, during 2005-2007
}

\author{
Venugopal Dhananjayan $^{1,2} \cdot$ Subramanian Muralidharan ${ }^{1}$
}

Published online: 5 February 2016

(C) Springer-Verlag Berlin Heidelberg 2016

Erratum to: Environ Sci Pollut Res (2013) 20:3414-3422

DOI 10.1007/s11356-012-1282-5

The list of authors was incorrect. Subramanian Muralidharan is a co-author of the paper. The complete author list and affiliations are presented in this article.

The acknowledgments section also contains a mistake. This should be:

\section{Acknowledgments}

This study was supported by SACON's Research and Development fund. We sincerely thank the Forest Department, Govt. of Gujarat for granting permission. We appreciate the help of Messrs Kartik Shastri and Rahgul Seghal, Ahmedabad

The online version of the original article can be found at http://doi.dx.org/ $10.1007 / \mathrm{s} 11356-012-1282-5$.

Venugopal Dhananjayan

dhananjayan_v@yahoo.com

1 Division of Ecotoxicology, Sálim Ali Centre for Ornithology and Natural History, Coimbatore 641 108, India

2 Present address: Industrial Hygiene and Toxicology Division, Regional Occupational Health Centre (Southern), ICMR,

Kannamangala (PO), Devanahalli (TK), Bangalore - 562110, India 